\title{
Considering Social Aspects of Geothermal Project: The Case of Social Mapping of Geothermal Project on Mount Ungaran
}

\author{
Budi Setiyono ${ }^{1}$, Agus Setyawan ${ }^{1}$, Jamari ${ }^{1}$, Heru Susanto ${ }^{1}$, Eko Punto ${ }^{1}$, Yogaribowo ${ }^{1}$, Wahid Abdulrahman ${ }^{1}$, Aris Edi \\ Susangkiyono ${ }^{2}$, Risman Chandra Budiman ${ }^{2}$, Yuafrinaldi ${ }^{3}$, Zukruf Delfa $^{3}$ \\ ${ }^{1}$ Institute for Research and Community Service of Diponegoro University, Semarang - Indonesia \\ ${ }^{2}$ State Electricity Company, Jakarta - Indonesia \\ ${ }^{3}$ Ametis Institute, Jakarta-Indonesia
}

\begin{abstract}
The development of renewable energy is an important step to reduce dependence on fossil energy. Geothermal energy is one source of renewable energy in Indonesia. However, when a geothermal project is not managed properly, the social political and cultural conditions of the community can be a failure factor in geothermal development. Through mix methods, this research undertakes social mapping in the project of Mount Ungaran as one of the geothermal development sites. Socially the people in the project area typically are rural communities where the role of informal leaders is very influential. There are a number of communities and non-governmental organizations that disagree with the development plan due to environmental, cultural and economic damage concerns. Yet, political support was obtained from the regional government and village government.
\end{abstract}

Keywords: Social mapping; geothermal project; geothermal energy; social impacts; Mount Ungaran

\section{Introduction}

According to data from the Ministry of Energy and Mineral Resources in 2018, the potential of renewable energy in Indonesia reaches $256.16 \mathrm{GW}$ comprising water potential of $75 \mathrm{GW}$, bioenergy potential of 32.6 $\mathrm{GW}$, wind potential of $60.6 \mathrm{GW}$, solar potential of 207.8 $\mathrm{GW}$, energy ocean of $17.9 \mathrm{GW}$ and geothermal of 28.5 $\mathrm{GW}[1,2]$. However, the installed capacity of renewable energy as a whole is still very low, at around $3.60 \%$ of the total potential, which is $9.43 \mathrm{GW}$ [3]. This shows that the utilization of renewable energy in Indonesia is still low even though with the potential of such large resources. Table 1 shows the potential and installed capacity of renewable energy in Indonesia [3].

Geothermal is one type of renewable energy in Indonesia that has the potential to be developed. The geothermal potential in Indonesia is associated with the distribution of volcanoes in Indonesia which spread from Sumatra Island to Nusa Tenggara Islands and Sulawei Island (Fig. 1). With potential resources and reserves of around $28,508 \mathrm{MW}$ or $28.5 \mathrm{GW}$, geothermal can be used to meet electricity needs in Indonesia and help the mix target of the national energy of renewable energy. In addition, heat can also be used to reduce dependence on fossil energy, especially for electricity in Indonesia.

During the process of developing geothermal energy in Indonesia, there are several problems that must be faced. One of the problems is the rejection of the community around the project $[4,5]$.

\footnotetext{
* Corresponding author: budisetiyono@lecturer.undip.ac.id
}

Table 1. The potential and the installed capacity of EBT in Indonesia [3]

\begin{tabular}{|c|c|c|c|c|}
\hline $\begin{array}{c}\text { Num } \\
\text { ber }\end{array}$ & $\begin{array}{c}\text { Renewable } \\
\text { Energy }\end{array}$ & $\begin{array}{l}\text { Potential } \\
\text { Resources }\end{array}$ & $\begin{array}{l}\text { Installed } \\
\text { Capacity }\end{array}$ & $\begin{array}{c}\text { Installation } \\
\text { Ratio of } \\
\text { Potential } \\
\end{array}$ \\
\hline 1 & Geothermal & $\begin{array}{r}\text { Resource: } \\
11 \text { GW } \\
\text { Reserve: } \\
17,4 \text { GW }\end{array}$ & $\begin{array}{l}1,98 \\
\text { GW }\end{array}$ & $6,8 \%$ \\
\hline 2 & Hydro & $75 \mathrm{GW}$ & $\begin{array}{l}\text { PLTA: } \\
\text { 5,124 GW } \\
\text { PLTMH: } \\
\text { 0,206 GW }\end{array}$ & $7,11 \%$ \\
\hline 3 & Bioenergy & $32,6 \mathrm{GW}$ & $1,84 \mathrm{GW}$ & $5,64 \%$ \\
\hline 4 & Solar & $\begin{array}{c}1,56 \\
\text { GW } \\
(207,8 \\
\text { GWp })\end{array}$ & $\begin{array}{l}0,018 \mathrm{GW} \\
(0,09 \\
\mathrm{GWp})\end{array}$ & $0,04 \%$ \\
\hline 5 & Wind & $60,6 \mathrm{GW}$ & $\begin{array}{l}76,1 \mathrm{MW} \\
(0,0761 \\
\text { GW }) \\
\end{array}$ & $0,13 \%$ \\
\hline 6 & $\begin{array}{l}\text { Ocean } \\
\text { Wave }\end{array}$ & $17,9 \mathrm{GW}$ & & $\mathrm{n} / \mathrm{a}$ \\
\hline & TOTAL & $\begin{array}{r}256,16 \\
\text { GW } \\
\end{array}$ & 9,43 GW & $3,60 \%$ \\
\hline
\end{tabular}

As in the plan to build a geothermal electric power plant on Mount Talang, Solok, West Sumatra. Hundreds of local people rallied to the Solok Regent's office. This happens because the community is concerned that the construction of a geothermal power plants will have an impact on the environment and the agricultural sector. In 
addition, the community is also concerned that the exploitation around Mount Talang will have an impact on the beauty of the natural surroundings. Such is the case in Mount Lawu and Bedugul where cultural aspects are part of the community's rejection.

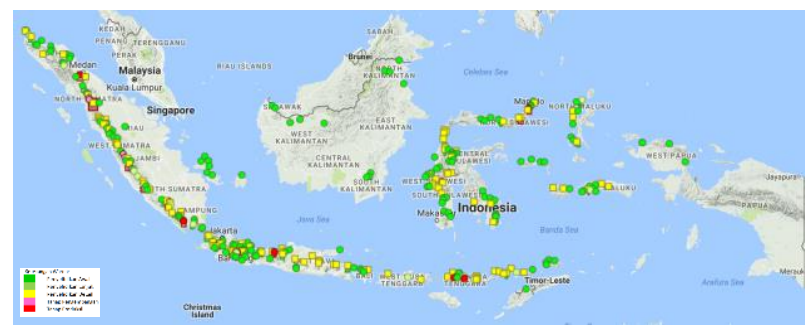

Fig. 1. Distribution potency gothermal resource in Indonesia [1]

Mount Ungaran located in Central Java is stratum volcanic typed consist of andesit and toadstone [6,7], geologically Mount Ungaran is in the Solo Zone that a line with Telomoyo, Merbabu and Merapi volcano (Figure 2). Moreover, the stratigraphy of the Ungaran Volcano consists of rocks lava andesite, lava perlitic, brexia volcanic during the cycle of Young and Old Ungaran [8]. Several geophysical and geochemistry research has been done to interpreted the subsurface structure and fluid flow hydrothermal system [9-13]. Based on the numerical simulation model the potential for electric power of Ungaran Geothermal has predicted 40-50 MW [14].

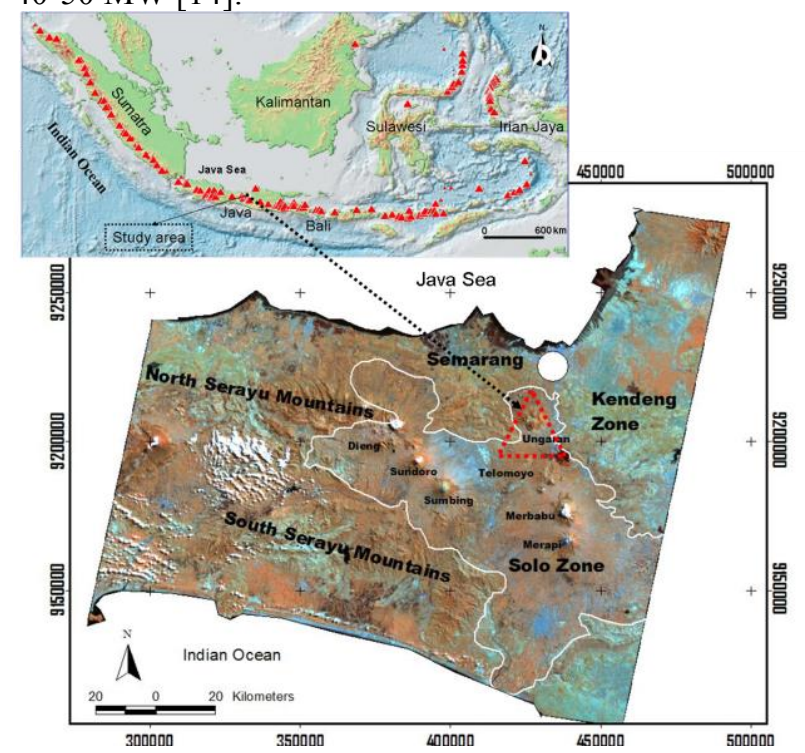

Fig. 2. Location of Mount Ungaran in Solo Zone which is a line with Telomoyo volcano, Merbabu volcano, and Merapi Volcano

Seeing the importance of understanding social, political, and cultural aspects of the community as a determining factor for the success of geothermal power plant construction, it is important to do a social mapping in the Mount Ungaran area with the aim of analyzing social, political, cultural conditions, perceptions of construction plans and potential conflicts in the Gedongsongo area of Mount Ungaran.

\section{Method}

The method used in this research was mixed methods. This research was a step of research by combining two existing studies namely quantitative research and qualitative research. According to [15], mixed research is a research approach that combines or associates quantitative forms and qualitative research. The research design used in this study was sequential exploratory, which is collecting and analyzing quantitative data then collecting and analyzing qualitative data. This study emphasized on qualitative methods. [15] argued that weights/priorities are more likely in the first stage, and the process of mixing between the two methods occurs when the researcher links between quantitative data analysis and qualitative data collection.

Qualitative analysis as the main element was descriptive analytical, a research model that is meant to make an analysis of the description of information data, events systematically, factual and accurate.

The qualitative approach has characteristics including collecting various forms of data, such as interviews, observations, and documents, rather than relying on a single data source. Then they reviewed all the data and gave meaning. The researchers with this approach observed the behavior and interviewed the participants while studying the documents (Creswell, 2015). While quantitative analysis was used through surveys of communities in the Mount Ungaran geothermal working area (WKP).

Primary data sources in this research were obtained through In-depth interviews, Focus Group Discussion, Observation, and Survey with a questionnaire. The survey was conducted in 26 villages (16 in the ring 1 area and 10 in the ring 2 areas) in the Gedongsongo Temple area (Semarang Regency and Kendal Regency) as geothermal centers on Mount Ungaran. In-depth interviews and FGDs were conducted with the Regency Government, police, military, village heads, religious leaders, women leaders, youth leaders, DPRD members, journalists and NGO activists.

\section{Results}

Socially, the community around the working area of Mount Ungaran project is a religious rural community in which religious social institutions are a means of social interaction. The character of rural communities is still very strong in the region where the social values of mutual cooperation and fraternal relations between citizens are still very close. From the perspective of social institutions, the existence of religious institutions and social institutions of society greatly influences social interactions including in the development process.

In some areas, the association is based on the development of culture into a developing institution as in Table 1. Village heads, hamlet heads, religious leaders, women, and youth are internal figures who have influence on the community development process around the working area of Mount Ungaran. In the construction process, external factors are represented in Non- 
Governmental Organizations (NGOs) that focus on environmental issues. These figures are a source of reference for citizens' information in the construction process, including the development plan.

\subsection{Perception of PLTP Constuction Plans}

In general, the majority of people in the working area of Mount Ungaran project (80.82 percent) gave their approval for the plan to develop a Geothermal Power Plant. In case with local governments that provide full support and hope that the construction will begin soon. The socialization process that has been carried out since 2010 has shaped the knowledge and expectations of citizens. However, there is still 17.12 percent of the people who disagree with the plan as shown in Figure 3. Strong support emerged from the regional government both the Central Java Provincy and the Semarang and Kendal Regency. This support was strengthened by the commitment of the local government to assist the implementation of construction plans at all stages.

Disagreements with the construction plans of the Mount Ungaran geothermal power plant also arose from NGO organizations caused by concerns about environmental damage, threat on cultural heritage and potential loss of livelihoods as shown in Table 2 and Table 3.

\subsection{2}

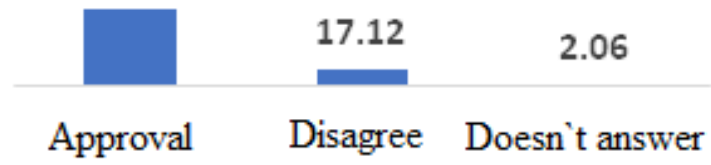

Fig. 3. Perception of people for development geothermal electric power plan in Mount Ungaran

Table 2. Map of Social Actors' Attitudes Toward PLTP Development Plans on Mount Ungaran

\begin{tabular}{|c|c|c|}
\hline Reject & $\begin{array}{c}\text { Accept with } \\
\text { Notes }\end{array}$ & Support \\
\hline 1. LSM & 1. LSM Bintari & 1. Pemprov Jawa \\
\hline Kompasi & 2. Journalist & Tengah \\
\hline 2. Yayasan & 3. Cagar Budaya & 2.Pemkab. Semarang \\
\hline Oemah & Jateng & 3.Pemkab. Kendal \\
\hline Bandungan & 4. Villages in & 4.Kodim Salatiga \\
\hline 3. Most & Limbangan & 5.DPRD Kendal \\
\hline business & Subdistrict, & Regency \\
\hline people in & Kendal Regency & 6.The association of \\
\hline & a.Pakis & NGO \& Community \\
\hline Gedongson & b. Gondang & Organization Putra \\
\hline go temple & 5.Villages in & Kendal \\
\hline area & Bandungan & 7.Polsek Bergas \\
\hline 4. Half of & Subdistrict, & 8.Villages in \\
\hline people in & Semarang & Limbangan \\
\hline some & Regency & Subdistrict, Kendal \\
\hline villages; & a.Munding & Regency \\
\hline Candi, & 1. Villages in & a. Ngesrepbalong \\
\hline Bandungan, & Bergas & b. Sumber \\
\hline Kenteng, & Subdistrict, & Rahayu \\
\hline
\end{tabular}

\begin{tabular}{|c|c|c|}
\hline Reject & $\begin{array}{l}\text { Accept with } \\
\text { Notes }\end{array}$ & Support \\
\hline $\begin{array}{l}\text { Nyatnyono, } \\
\text { Lanjan, } \\
\text { Mendongan } \\
\text {, Kemawi, } \\
\text { Losari, } \\
\text { Jubelan, } \\
\text { Sumowono }\end{array}$ & \begin{tabular}{l} 
Semarang \\
Regency \\
a. Wringin \\
\multicolumn{1}{c}{ Putih } \\
2. Villages in \\
Ungaran \\
Barat \\
Subdistrict, \\
Semarang \\
Regency \\
a.Gogik
\end{tabular} & $\begin{array}{l}\text { c. Sriwulan } \\
\text { d. Gonoharjo } \\
\text { 9.Villages in Boja } \\
\text { Subdistrict, Kendal } \\
\text { Regency } \\
\text { a. Medono } \\
\text { 10.Villages in } \\
\text { Sumowono } \\
\text { Subdistrict, Semarang } \\
\text { Regency } \\
\text { a.Kemawi } \\
\text { b. Bumen } \\
\text { c.Jubelan } \\
\text { d. Mendongan } \\
\text { e.Lanjan } \\
\text { f. Losari } \\
\text { 11.Villages in } \\
\text { Bandungan } \\
\text { Subdistrict, Semarang } \\
\text { Regency } \\
\text { a.Candi } \\
\text { b. Kenteng } \\
\text { c.Kel. Bandungan } \\
\text { d. Duren } \\
\text { e. Sidomukti } \\
\text { f. Pakopen } \\
\text { g. Jimbaran } \\
\text { 12.Villages Bergas } \\
\text { Subdistrict, Semarang } \\
\text { Regency } \\
\text { a.Gebugan } \\
\text { b. Pagersari } \\
\text { 13.Villages in } \\
\text { Ungaran Barat } \\
\text { Subdistrict, Semarang } \\
\text { Regency } \\
\text { a.Kalisidi } \\
\text { b. Nyatnyono } \\
\text { c.Lerep } \\
\text {. }\end{array}$ \\
\hline
\end{tabular}

Table 3. Reasons for Rejection

\begin{tabular}{|l|l|}
\hline $\begin{array}{c}\text { The party is } \\
\text { presently still } \\
\text { rejecting }\end{array}$ & \multicolumn{1}{|c|}{ Reasons for rejection } \\
\hline $\begin{array}{l}\text { SM Kompasi } \\
\text { (NGO) }\end{array}$ & $\begin{array}{l}\text { 1. Concern about environmental } \\
\text { damage } \\
\text { a. Poison gas } \\
\text { b. Earthquake } \\
\text { c. Damage to forests and } \\
\text { ecosystems }\end{array}$ \\
& $\begin{array}{l}\text { 2. Potential to cause traffic disruption } \\
\text { and safety when mobilizing heavy } \\
\text { equipment } \\
\text { 3. Damage to cultural heritage }\end{array}$ \\
\hline $\begin{array}{l}\text { Yayasan Oemah } \\
\text { Bandungan }\end{array}$ & $\begin{array}{l}\text { 1. Concern about damage to cultural } \\
\text { reserves } \\
\text { 2. Fear of losing livelihoods } \\
\text { 3. Concern about environmental } \\
\text { damage }\end{array}$ \\
\hline $\begin{array}{l}\text { Most business } \\
\text { people in the } \\
\text { Gedongsongo } \\
\text { temple area }\end{array}$ & $\begin{array}{l}\text { 1. Concern about damage to cultural } \\
\text { reserves } \\
\text { 2. Concern about reduced visitors }\end{array}$ \\
\hline $\begin{array}{l}\text { Half of people in } \\
\text { some villages; }\end{array}$ & $\begin{array}{l}\text { Concerns about the effects of reduced } \\
\text { water, earthquakes, loss of jobs, and }\end{array}$ \\
\hline
\end{tabular}




\begin{tabular}{|l|l|}
\hline $\begin{array}{c}\text { The party is } \\
\text { presently still } \\
\text { rejecting }\end{array}$ & \multicolumn{1}{|c|}{ Reasons for rejection } \\
\hline Candi, & \\
Bandungan, & roads are damaged \\
Kenteng, & \\
Nyatnyono, & \\
Lanjan, & \\
Mendongan, & \\
Kemawi, Losari, & \\
Jubelan, & \\
Sumowono & \\
\hline
\end{tabular}

\subsection{Potential Conflicts}

Souronding the geothermal prospect area of Mount Ungaran has no history of development conflict. However, there are still potential conflicts in the development of geothermal power plants. This is caused by the knowledge and concerns of the community, businesses, and non-governmental organizations regarding environmental damage, damage to cultural heritage, damage to roads and concerns about the loss of part of the residents' livelihoods.

The potential of the conflict has begun to appear on the surface with the emergence of rejection on behalf of residents around the Gedongsongo temple as well as news through social media/whatsapp circulating with the message of the negative impact of the construction of geothermal power plants. Likewise, the rejection movements that have been known by the Police,such as the plan to spread the rejection banners at the Indonesia Independence Day commemorative carnival and the plan of painting contest at Gedongsongo Temple by raising the theme of rejection of the construction of geothermal power plants.

\subsection{Suggestions for Corporate Social Responsibility Program}

Based on the results of a field survey, in order to gain community support related to the development of geothermal on Mount Ungaran, the CSR programs need to include a total of 28 villages located nearby the project area. The programs should cover activities that can be categorized into 4 (four) fields, including education, economy, culture, and health.

In education sector, the proposed CSR programs should focus on provision of educational facilities and infrastructure (buildings and libraries), scholarships, books, as well as trainings such as entrepreneurial training and youth training (soft skills and hard skills). Then in the economic field, the proposed CSR programs should focus on the development of tourism and venture capital for the community. Furthermore, in the field of culture, the proposed CSR programs may focus on the fostering and procurement of facilities and infrastructure for arts performing activities in the community both tradiitional and contemporer art. Whereas in the health sector, the proposed CSR program may focus on the improvement and addition of health facilities and infrastructures such as health centers, clean water, garbage bins, and sports venues. In addition, other CSR programs may also include general check up and free medical treatment to communities.

\section{Conclusion}

Social mapping shows that the community in geothermal prospect area of Mount Ungaran is a rural community with the role of community leaders, religion, women and village officials who are very central in the development process. The existence of social, religious and cultural organizations plays an important role in social interaction. Even though the majority of the community currently supports the geothermal development plan on Mount Ungaran (Gedongsongo Temple area), there are still communities and non-government organizations that reject it. The rejection was due to concerns about the potential for environmental damage such as a reduction in clean water sources, mudflows, earthquakes and forest destruction. Culturally, it is also feared that it will damage the temple area. Strong support came from local and village governments. Therefore it is important to conduct more intensive dialogue and coordination to provide understanding to the community and undertake corporate social responsibility programs that meet the needs of community nearby geothermal development projects.

\section{References}

1. EBTKE-ESDM, Indonesian geothermal GIS, http://pabum.ebtke.esdm.go.id/gis (2017)

2. EBTKE-ESDM, Potential of renewable energy, https://redi.esdm.go.id/ (2018)

3. ESDM, Handbook of energy \& economic statistics Indonesia, Jakarta, Kementerian ESDM RI (2018)

4. H. P. Manfred, and S. Sudarman, History of geothermal exploration in Indonesia from 1970 to 2000, Geothermics, 220-266, (2008).

5. A. Manzella, R. Bonciani, A. Allansdottir, S. Botteghi, A. Donato, S. Giamberini, ... D. Scrocca, Environmental and social aspects of geothermal energy in Italy, Geothermics, 232-248 (2018)

6. R. Bemmelen, The Geology of Indonesia (2th Edition), Den Haag, Martinus Nijhoff (1970).

7. N. Budiardjo, \& M. Budihardi, Resources characteristics of the Ungaran field, Central Java, Indonesia, Proceedings of the national seminar of human resources Indonesia geologist, Geological engineering mineral (1997)

8. R. E. Thanden, H. Sumadirdja, P. W. Richards, K. Sutisna, \& T. C. Amin, Geological map of the Magelang and Semarang sheets, Java, scale 1:100.000 Indonesia: Geological research and development centre (1996)

9. A. Setyawan, Y. Fujimitsu, K. Fukuoka, J. Nishijima, S. Ehara, H. Saibi, Geophysical investigation of Ungaran volcano, Central Java, Indonesia, Proceedings $29^{\text {th }}$, New Zealand (2007)

10. E. Z. Gaffar, D. D. Wardhana, \& D. S. Widarto, Integrated geophysical study on the Southern slope 
of Mount Ungaran, Jurnal Meteorologi dan Geofisika, 101-119 (2007)

11. F. Tarmidzi, \& A. Setyawan, Study of fluid flow in Gedongsongo temple manifestation geothermal based on geophysics data, Energy Procedia, 101107, (2014).

12. Y. Aribowo, P. Utami, \& Wahyudi, Fluid geochemistry and hydrothermal alteration study of Gedongsongo manifestation area, Ungaran geothermal prospect, Proceeding of IAGI Annual Meeting (2002)

13. N. K. Phuong, H. Hendrayana, A. Harijoko, R. Itoi, \& R. Unoki, Geochemistry of the Ungaran geothermal system, Central Java, Indonesia, Proceedings Joint Conference HAGI-IAGIPERHAPI, Surabaya (2005)

14. A. Setyawan, S. Ehara, Y. Fujimitsu, \& J. Nijishima, An estimate of the resource of Ungaran geothermal prospect for Indonesia power generation, Proceedings world geothermal congress, Bali (2010)

15. J. W. Creswell, Research design: qualitative, quantitative and mixed, methods approaches : fourth edition, Sage publications (2014) 